\title{
Enhanced Peroxidase Activity of Hemoglobin in a DNA Membrane and Its Application to an Unmediated Hydrogen Peroxide Biosensor
}

\author{
Libin Shang, Ziyi Sun, Xingwu Wang, and Genxi Li ${ }^{\dagger}$ \\ Department of Biochemistry and National Key Laboratory of Pharmaceutical Biotechnology, \\ Nanjing University, Nanjing 210093, P. R. China
}

\begin{abstract}
Hemoglobin can exhibit not only a direct electron transfer reacting after being entrapped in a DNA membrane, but also a greatly enhanced peroxidase activity toward the reduction of hydrogen peroxide. Based on the direct electrochemical property and nice enzymatic activity of the protein in a DNA membrane, a reagentless hydrogen peroxide biosensor was prepared. The peak current related to hydrogen peroxide was linearly proportional to its concentration in the range of $1.9 \times 10^{-6}-6.8 \times 10^{-4} \mathrm{~mol} \mathrm{~L}^{-1}$. The detection limit was $1 \times 10^{-6} \mathrm{~mol} / \mathrm{L}$
\end{abstract}

(Received June 9, 2003; Accepted August 15, 2003)

\section{Introduction}

Hemoglobin $(\mathrm{Hb})$ is a physiological oxygen-transport protein in red blood cells and thus of great importance for research both in vivo $^{1}$ and in vitro. ${ }^{2}$ Studies on its structure-function relationship have intrigued researchers over the years. As is well known, electrochemical methods have proven to be powerful tools for detecting and evaluating the structure-function relationship of

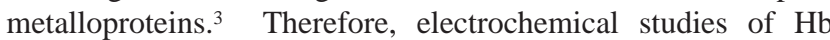
might help to investigate its physiological functions. However, since $\mathrm{Hb}$ is not designed as an electron-transfer (eT) protein, it is difficult for $\mathrm{Hb}$ to exhibit heterogeneous eT processes, which means that the eT reactivity of $\mathrm{Hb}$ is very slow. ${ }^{4-6}$

Others and we have found that many eT proteins are strongly membrane-associated, and a certain kind of organized molecular structure in the membrane is necessary for their efficient eT. ${ }^{7-11}$ Although DNA is widely known as the preferred gene-storage medium, it also has a well characterized structure, which can be used as a useful material to create well defined structures on molecular level. ${ }^{12}$ Therefore, the interaction between DNA and proteins has become one of the principal biological interactions, and heme protein-DNA complexes have attracted much recent interest. ${ }^{13-16}$ Our previous studies have shown that $\mathrm{Hb}$ entrapped in a DNA membrane exhibits a nice eT reactivity. ${ }^{17,18}$

The interaction between membranes and proteins may also help to obtain and enhance the intrinsic catalytic ability of proteins. $\mathrm{Hb}$ has some intrinsic peroxidase activity due to its close similarity with peroxidases. However, compared with horseradish peroxidase and other peroxidases, its ability to catalyze the reduction of hydrogen peroxidase $\left(\mathrm{H}_{2} \mathrm{O}_{2}\right)$ is quite limited. Previous studies revealed that the peroxidase activity of $\mathrm{Hb}$ can be greatly enhanced through noncovalent interactions with some membranes. ${ }^{19,20}$ Studies on this promotion may not only reveal possible interactions between the protein and membranes, but also provide an alternative and convenient way to enzyme engineering, which is useful in many application

\footnotetext{
† To whom correspondence should be addressed.

E-mail: genxili@nju.edu.cn
}

areas, including the development of new biosensors. In this work, we report that $\mathrm{Hb}$ shows a greatly enhanced catalytic ability toward the reduction of $\mathrm{H}_{2} \mathrm{O}_{2}$ after being entrapped in the DNA membrane. Based on these studies, an unmediated $\mathrm{H}_{2} \mathrm{O}_{2}$ biosensor has been successfully prepared.

\section{Experimental}

\section{Reagents}

$\mathrm{Hb}$ was obtained from Serva and used without further purification. Their stock solutions were stored at a temperature of $4^{\circ} \mathrm{C}$. Salmon sperm DNA (sodium salt) was purchased from Sigma, USA, and was further purified by extraction with phenol and chloroform, and precipitation with ethanol. Other reagents were of analytical grade. Water was purified with a Milli-Q purification system to a specific resistance of $>16 \mathrm{M} \Omega \mathrm{cm}^{-1}$, and was used to prepare all solutions.

\section{Apparatus}

Cyclic voltammetry (CV) was performed with a PAR 263 Potentiostat/Galvanostat (EG\&G, USA). A three-electrode configuration was employed. The cell was a $10 \mathrm{ml}$, single electrolyte compartment. The working electrode was a pyrolytic graphite $(\mathrm{PG})$ disk electrode $\left(A=6.38 \mathrm{~mm}^{2}\right)$. The PG electrode was prepared by pressing a PG rod into a glass tube, then fixing it by epoxy resin. A saturated calomel electrode (SCE) was used as a reference electrode, and all potentials reported here were referred to it. A platinum wire electrode served as a counter electrode.

\section{Preparation of an Hb-DNA modified electrode}

The substrate PG electrode was first polished using rough and fine sand paper. It was then polished to mirror smoothness with an alumina (particle size of about $0.05 \mu \mathrm{m}$ )/water slurry on silk. After that, it was ultrasonicated in both water and ethanol for about $2 \mathrm{~min}$. An aqueous mixture of $7 \mathrm{ml}$ of $0.1 \mathrm{mM} \mathrm{Hb}$ and 3 $\mathrm{ml}$ of $1 \mathrm{mg} / \mathrm{ml}$ dsDNA was spread evenly onto the surface of the substrate PG disk electrode. Alternatively, only DNA or only $\mathrm{Hb}$ was cast onto a PG electrode. An eppendorf tube was fitted 

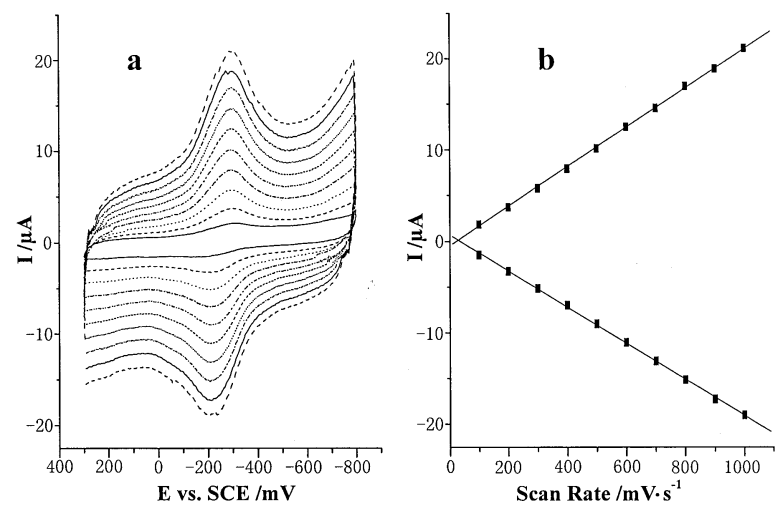

Fig. 1 (a) A series of cyclic voltammograms obtained at an $\mathrm{Hb}-$ DNA modified PG electrode in a $0.1 \mathrm{M}$ Hac-NaAc buffer solution, $\mathrm{pH}$ 4.0. Scan rate, from 100 to $1000 \mathrm{mV} / \mathrm{s}$. (b) Plot of the redox peak currents with the scan rate.

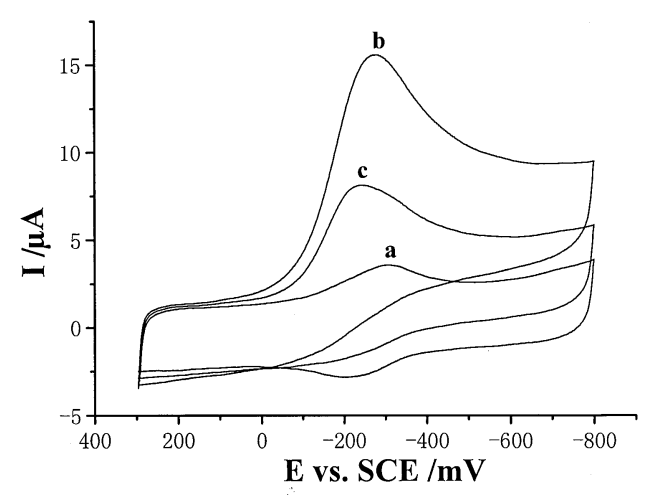

Fig. 2 Cyclic voltammograms obtained at an Hb-DNA modified PG electrode for a $0.1 \mathrm{M}$ Hac-NaAc buffer solution, $\mathrm{pH} 4.5$, (a) before and (b) after the addition of $0.3 \mathrm{mM} \mathrm{H}_{2} \mathrm{O}_{2}$ to the buffer solution. (c) Cyclic voltammogram obtained at an $\mathrm{Hb}$-alone modified PG electrode (free of DNA) for the $\mathrm{H}_{2} \mathrm{O}_{2}$ solution. Scan rate, 200 $\mathrm{mV} / \mathrm{s}$.

over the electrode for $2 \mathrm{~h}$ to ensure that water evaporated slowly and a more uniform membrane structure was formed. This electrode was then dried overnight at room temperature. Finally, the electrode was thoroughly rinsed with pure water and was ready for use. The modified electrode was kept in a phosphate buffer solution with $\mathrm{pH} 7.0$ at $4^{\circ} \mathrm{C}$ when not in use.

\section{Electrochemical measurements}

The test solutions were citric acid buffer solution, phosphate buffer solution and Glycerol-NaOH buffer solution. The potential range of $\mathrm{CV}$ was between 300 and $-800 \mathrm{mV}$, scanning in the negative direction. Cyclic voltammograms were recorded until a steady response was obtained. Prior to the determination, the test solution was bubbled thoroughly with high-purity nitrogen. Then, a stream of nitrogen was blown gently across the surface of the protein solution in order to maintain the solution anaerobic throughout the experiment.

\section{Results and Discussion}

Our previous study proved that DNA could provide a desirable membrane environment for $\mathrm{Hb}$ to undergo facile $\mathrm{eT}$

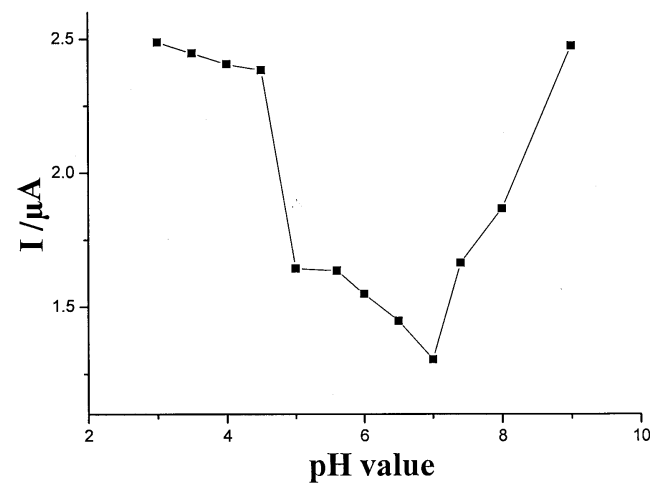

Fig. 3 Dependence of the reduction peak of $\mathrm{H}_{2} \mathrm{O}_{2}\left(I_{\mathrm{pc}}\right)$ on $\mathrm{pH} . \mathrm{H}_{2} \mathrm{O}_{2}$ concentration: $0.1 \mathrm{mM}$. Scan rate: $100 \mathrm{mV} / \mathrm{s}$.

reactions. ${ }^{17,18}$ Figure 1 shows a series of cyclic voltammograms obtained at an Hb-DNA modified PG electrode with different scan rates. It is observed that both the anodic and cathodic peak currents for $\mathrm{Hb}$ are linearly proportional in the range of 100 to $1000 \mathrm{mV} / \mathrm{s}$, while the formal potentials remain almost unchanged. This is a characteristic of thin-layer electrochemical behavior. Nearly all electroactive $\mathrm{HbFe}(\mathrm{III})$ is reduced to $\mathrm{HbFe}(\mathrm{II})$ on the forward $\mathrm{CV}$ scan, and vice versa. ${ }^{21}$

Further studies revealed that the peroxidase activity of the protein is greatly enhanced after it is entrapped in the DNA membrane. As shown in Figs. $2 a$ and $2 b$, the voltammogram changes significantly after the addition of $\mathrm{H}_{2} \mathrm{O}_{2}$ into the buffer solution. The cathodic peak located at about $-171 \mathrm{mV}$ apparently increases upon the addition of $\mathrm{H}_{2} \mathrm{O}_{2}$, accompanied by a decrease in the anodic peak, which represents a catalytic electrochemical reduction toward $\mathrm{H}_{2} \mathrm{O}_{2}$. The greater was the addition of $\mathrm{H}_{2} \mathrm{O}_{2}$, the higher was the reduction peak current. In contrast, no corresponding electrochemical signal was observable when employing either a bare PG electrode or a DNA-alone modified $\mathrm{PG}$ electrode in the same $\mathrm{H}_{2} \mathrm{O}_{2}$ solution.

Compared with the Hb-DNA modified PG electrode, the reduction peak current obtained at the $\mathrm{Hb}$-alone modified electrode was much lower at the same $\mathrm{H}_{2} \mathrm{O}_{2}$ concentration (Fig. $3 c$ ). This result clearly indicates that the peroxidase activity of $\mathrm{Hb}$ was greatly enhanced in the DNA membrane. Although the mechanism is still unclear, it is obvious that DNA exerts an important effect on the catalytic ability of $\mathrm{Hb}$.

This result suggests that $\mathrm{Hb}$ incorporated in the DNA membrane may function as an effective catalyst to the reduction of $\mathrm{H}_{2} \mathrm{O}_{2}$, thus providing an opportunity to apply this Hb-DNA modified electrode to the determination of $\mathrm{H}_{2} \mathrm{O}_{2}$. For this purpose, the optimum $\mathrm{pH}$ value for the reduction of $\mathrm{H}_{2} \mathrm{O}_{2}$ should be examined. Figure 3 shows the dependence of the $\mathrm{H}_{2} \mathrm{O}_{2}$ reduction peak current on the $\mathrm{pH}$ at an $\mathrm{Hb}$-DNA modified PG electrode. A reversed bell-shaped curve is observed in the $\mathrm{pH}$ range of 3-9. The peak current seems to be higher when using a more acidic or basic buffer. However, the Hb-DNA complex is not very stable under such conditions. For instance, the peak current obtained at the modified electrode decreased about $25 \%$ after being repetitive scanned for 20 cycles in a background solution with $\mathrm{pH}$ 3.0. Therefore, $\mathrm{pH} 4.5$ is chosen to be the optimum $\mathrm{pH}$ value to build a $\mathrm{H}_{2} \mathrm{O}_{2}$ biosensor.

The calibration curve (Fig. 4) shows the linear dependence of the cathodic peak current on the $\mathrm{H}_{2} \mathrm{O}_{2}$ concentration in the range of $1.9 \times 10^{-6}-6.8 \times 10^{-4} \mathrm{~mol} / \mathrm{L}$. The relative standard deviation is $2.9 \%$ for 5 successive determinations at $1 \times 10^{-5} \mathrm{~mol} / \mathrm{L}$. The detection limit is $1 \times 10^{-6} \mathrm{~mol} / \mathrm{L}$. 


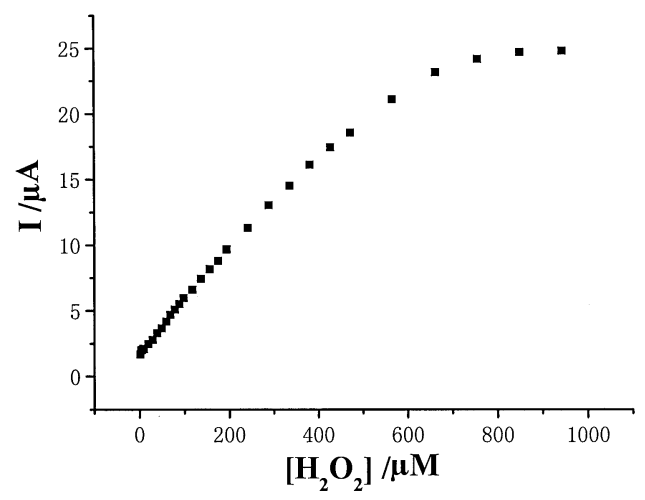

Fig. 4 Plot of the catalytic peak current versus the concentration of $\mathrm{H}_{2} \mathrm{O}_{2}$. Others same as Fig. 2 .

The stability of this $\mathrm{H}_{2} \mathrm{O}_{2}$ sensor was also tested. The HbDNA modified electrode was dried and stored in air, and CV was run twice a week after returning the electrode to a citric acid buffer solution containing $1 \times 10^{-5} \mathrm{~mol} / \mathrm{L} \mathrm{H}_{2} \mathrm{O}_{2}$. The catalytic peak current decreased slowly during the first week for about $10 \%$, and afterwards the peak current was essentially stable for at least 1 month.

\section{Acknowledgements}

We thank the National Natural Science Foundation of China (Grant No. 30070214) and the Chinese Ministry of Education (Grant No. 01087) for financial support.

\section{References}

1. R. Gabbianelli, A. M. Santroni, D. Fedeli, A. Kantar, and G. Falcioni, Biochem. Biophys. Res. Commun., 1998, 242, 560.
2. J. Glanz, Science, 1996, 271, 1670.

3. F. A. Armstrong, H. A. Heering, and J. Hirst, Chem. Soc. Rev., 1997, 26, 169.

4. J. Ye and R. P. Baldwin, Anal. Chem., 1988, 60, 2263.

5. D. Schlereth and W. Mantele, Biochemistry, 1992, 31, 7494.

6. E. Stellwagen, Nature, 1978, 275, 73.

7. Z. Salamon, J. T. Hazzard, and G. Tollin, Proc. Natl. Acad. Sci. U.S.A., 1993, 90, 6420 .

8. I. Hamachi, A. Fujita, and T. Kunitake, J. Am. Chem. Soc., 1997, 119, 9096.

9. P. Bianco and J. Haladjian, J. Electrochim. Acta, 1997, 42, 587.

10. Z. Lu, Q. Huang, and J. F. Rusling, J. Electroanal. Chem., 1997, 423, 59.

11. C. Fan, Y. Zhuang, G. Li, J. Zhu, and D. Zhu, Electroanalysis, 2000, 12, 1156.

12. C. M. Niemeyer, M. Adler, B. Pignataro, S. Lenhert, S. Gao, L. Chi, H. Fuchs, and D. Blohm, Nucleic Acids Res., 1999, 27, 4553 .

13. R. Sauer and S. Harrison, Curr. Opin. Struc. Biol., 1996, 6, 51

14. D. J. F. Chinnapen and D. Sen, Biochemistry, 2002, 41, 5202.

15. P. Travascio, A. Bennet, D. Wang, and D. Sen, J. Am. Chem. Soc., 2001, 123, 1337.

16. A.-E. F. Nassar and J. F. Rusling, J. Am. Chem. Soc., 1996 , $118,3043$.

17. C. Fan, G. Li, J. Zhu, and D. Zhu, Anal. Chim. Acta, 2000, 423,95

18. L. Shang, X. Liu, J. Zhong, C. Fan, I. Suzuki, and G. Li, Chem. Lett., 2003, 32, 296.

19. I. Hamachi, A. Fujita, and T. Kunitake, J. Am. Chem. Soc., 1994, 116, 8811.

20. A. Fujita, H. Senzu, T. Kunitake, and I. Hamachi, Chem. Lett., 1994, 1219.

21. A. J. Bard, "Electroanalytical Chemistry", 1984, Marcel Dekker, New York. 